\title{
Appraisal of Groundwater Potential of Fadama Areas within Northern Nigeria: A Review
}

\author{
Martin 0. Eduvie1, Muhammad L. Garba² \\ ${ }^{1}$ National Water Resources Institute, Kaduna, Nigeria \\ ${ }^{2}$ Department of Geology, Ahmadu Bello University, Zaria, Nigeria \\ Email:martineduvie@gmail.com, muhawwal@gmail.com
}

How to cite this paper: Eduvie, M. O., \& Garba, M. L. (2021). Appraisal of Groundwater Potential of Fadama Areas within Northern Nigeria: A Review. Journal of Geoscience and Environment Protection, 9, 44-57.

https://doi.org/10.4236/gep.2021.93004

Received: January 20, 2021

Accepted: March 14, 2021

Published: March 17, 2021

Copyright $\odot 2021$ by author(s) and Scientific Research Publishing Inc. This work is licensed under the Creative Commons Attribution International License (CC BY 4.0).

http://creativecommons.org/licenses/by/4.0/

\begin{abstract}
Nigeria is a country endowed with alluvial aquifers that occur along major river valleys, in low lying areas which are frequent to flooding during the rainy season. They are scattered across the ecological zones of Guinea savannah, Sudan savannah and the Sahel Savannah and are the thickest along the river Niger and river Benue. The irrigated flood plains (Fadama) are formed by the deposition of transported weathered exogenic terrigenous materials derived from the surrounding basement rocks. These shallow aquifers are mostly unconfined and are recharged through flash flooding events which make them hold great groundwater resources for dry season farming. The fertility of the soils with their residual moisture content makes them attractive for dry season farming. The potential and importance of Fadama agriculture for food production and economic development are crucial, given the recent rising food prices, climatic changes, environmental risks associated with "modern" agriculture, modelled farming systems and population growth. Fadama areas are therefore of critical importance to the survival and economic development of millions of rural dwellers. This paper reviews the groundwater potential of the Floodplains of Fadama for dry farming systems in semi-arid northern Nigeria.
\end{abstract}

\section{Keywords}

Sudan Savannah-Sahel Region, Semi-Arid, Fadama, Shallow Alluvial Aquifer, Floodplains, Irrigation, Northern Nigeria

\section{Introduction}

Nigeria is a country which has abundant water resources for both domestic and agricultural uses. Three broad ecological zones are commonly distinguished in 
the country: 1) The northern Sudan Savannah; 2) The Guinea Savannah zone or Middle Belt; and 3) The southern rainforest zone. Based on rainfall and temperature, the country is divided into 8 hydrological areas drained mainly by the River Niger and River Benue and their numerous minor tributaries. Along these rivers, beds lie the flood plains (locally termed as Fadama) on which lies fertile soil mostly used for dry season irrigation due to its inundation by flooding during the wet season. These floodplains consist of alluvial aquifers with shallow groundwater occurring at shallow depths of 3 - 4 m below the surface, Tarhule \& Woo, (1997).

Nigeria is by far the most populous country in Africa, with its over 180 million people (2018 estimate). Population density is 195 inhabitants $/ \mathrm{km}^{2}$, annual growth rate is 2.2 percent and 52 percent of the population is rural where agricultural practice is still at its subsistence level. This makes it difficult to attain self-sufficiency in food production without embarking on dry season farming mostly practiced along the flood terraces (Fadamas) at small scale by the subsistence farmers.

The irrigation potential of Nigeria is put at 2.0 million hectare out of this only 900,000 hectare is being utilized, with $70 \%$ of the potential occurring in northern Nigeria, with just $20 \%$ is occurring in the south and the balance of $10 \%$ located in the highland areas of central and western Nigeria Tarhule \& Woo, (1997).

The irrigated floodplains (Fadama) are formed by the deposition of transported weathered exogenic terrigenous materials derived from the surrounding basement rocks. They are mostly of local occurrence except along the courses of major rivers like Rima in the Northwest and the Hadejia Jama'are to the northeastern part of the country Swindell (1986). Fadama is not only important for their irrigation potentials but also as a major source of freshwater for domestic consumption, livestock grazing and watering in sub-Saharan Africa Tarhule, \& Woo, (1997). But their major use is for the production of agricultural surplus (particularly of rice and vegetables) in order to support the food requirement of the local population and at the same time improve on their economy.

According to Food and Agricultural Organisation (FAO), Nigeria is among those nations that are at the moment technically and are unable to meet their food needs from rain fed production despite wide range of agro-ecological zones, which allows for a diversity of crop production activities. This is simply because Farming systems are mainly small holder-based and agricultural landholdings are scattered, Aquastat survey (2005). This paper intends to review the groundwater potential of the flood plains areas for dry season farming in northern Nigeria.

\section{The Study Area}

The study focuses on the Northern part of Nigeria were most of the Fadama/Floodplains are located, and which covers parts of the North-western, 
North-eastern and North-Central Nigeria distributed across the savannah, Sahel, Arid and Semi-arid region, Figure 1.

In the northwest, the Sokoto Rima basin is ecologically one of the most marginal regions for agriculture in Nigeria due to its irregular rainfall distribution. It is divided into 3 physiographic regions according to Swindell (1986).

1) The upland or high plain of the east and the southeast,

2) The Sokoto plain of the north and central part, and

3) The riverine regions of the Niger and lower Rima valleys.

\subsection{Potential Areas of Shallow Ground Water Development in the Sokoto/Rima Basin}

Fadama areas in the Sokoto/ Rima area with potential for shallow groundwater development were identified by WEC (1988). These they categorized into major, intermediate and minor Fadama with an estimate of their areas. A total area of 280,000 hectares was identified as having significant potential. The major Fadamas of the Niger and Sokoto/Rima River floodplain constitute over 60 percent of the potential development area. Moreover these Fadamas are rated as having the best potential and the highest yield from individual tube wells. Their aquifers are made up of alluvial sands which attain a thickness of over 25 metres on the Niger River floodplain and up to 15 metres on the Sokoto/Rima floodplain.

Intermediate fadamas constitute almost 20 percent of the potential area. Most of these fadamas are classified as having good potential but some unsuccessful tube wells should be expected. The aquifers are primarily alluvial sands and gravels 8 to 15 metres thick. An exception is the Zamfara River floodplain where alluvial sands over 20 metres thick have been intersected in a test hole at Gummi.

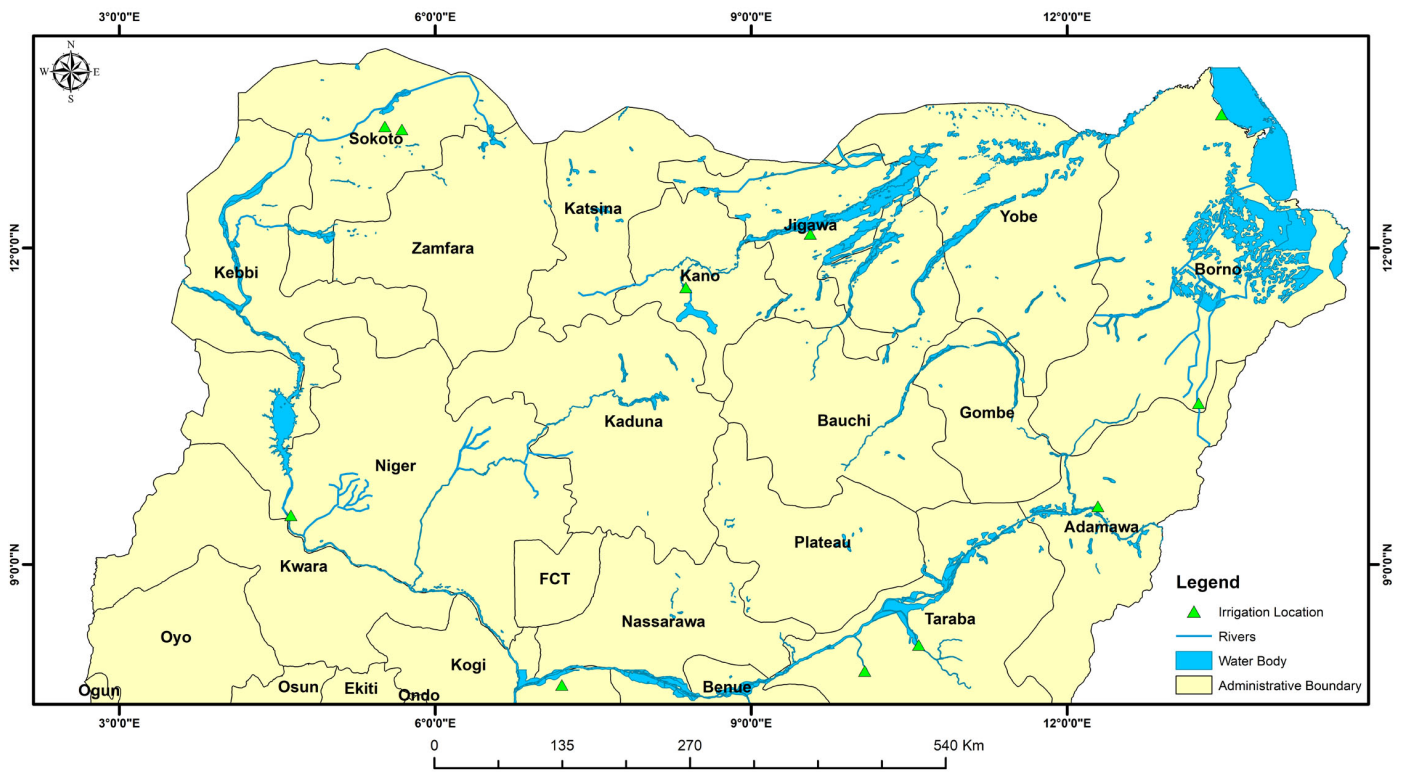

Figure 1. Drainage map of part of Nigeria showing the major irrigation schemes (Hollis \& Thompson, 1993). 
Minor fadamas make up the balance of the total. Most of these are either small isolated alluvial deposits or long narrow floodplains having moderate to low potential. The aquifers in the sedimentary terrain are mainly fine to medium grained alluvial sands and underlying sedimentary sandstones. On the minor fadamas in the crystalline terrain the aquifers are alluvial sands and fine gravels which have limited areal extent and change rapidly in their ability to transmit water. Tube well yields from these water bearing zones vary considerably. Wells completed in the coarse sand and fine gravel zones have yields over $300 \mathrm{l} / \mathrm{m}$. whereas within a short distance a tube well in a finer portion of the deposit will be reduced to $60 \mathrm{l} / \mathrm{m}$.

The Rima fadama spans from Sabon-Birnin in the east through Sokoto, Argungu, Birnin Kebbi, up to Bunza in Kebbi state Swindell (1986). The general trend of annual rainfall distribution shows greater rainfall in the south (1008 $\mathrm{mm}$ ) with an onset of the rain around April while further North around Sokoto town the rainfall averaged $740 \mathrm{~mm}$ which drop to $658 \mathrm{~mm}$ at the Northern edge of close settled zone where the rain did not usually start until June and in some years finish by mid-September.

According to WEC (1988), the Sokoto/Rima zone has 2 million hectares of arable land out of which 1 million hectares is cultivated under rainfall condition, again, there are 425,000 hectares of irrigable land out of which 225,000 hectares are of high potential, however out of this total, only 60,000 hectares is now under various types of irrigation where garlic, onions, tomatoes rice and occasionally wheat dominate dry season crops. With the alluvial aquifer yielding on average 1.0 to $5.0 \mathrm{l} / \mathrm{s}$, AQUASTAT survey (2005).

The alluvial sands and fine gravel aquifers have transmissibilities in the range 400 to $1200 \mathrm{~m}^{2} /$ day and storage coefficients in range $10^{-2}$ to $10^{-4}$ based on three pumping tests, indicating semi-confined conditions. Complex aquifer conditions are reflected in boundary conditions. Water levels were not monitored but are expected to fluctuate an average of less than $1.5 \mathrm{~m}$ over the dry season/rainy season cycle. The lowest water levels occur in May and the highest water levels in October/November. Recharge to the aquifer occurs through infiltration of surface waters during the rainy season and is augmented by upward flow from the underlying sedimentary bedrock formations Figure 2 .

\subsubsection{Sokoto/Rima Floodplain}

The alluvial sands and fine gravels comprise the main aquifers and have transinissibilities in the range 200 to $5000 \mathrm{~m}^{2} /$ day and storage coefficients $10^{-2}$ to $10^{-4}$ based on ten pumping tests. As reported by WEC (1988), the highest transmissibilities occur in the lower portion of the floodplain between Bunza and Bagudo. Where semi-confined to confined aquifer conditions are indicated. Complex aquifer conditions are indicated by hydraulic boundaries in the pumping test plots. Lateral changes in transmissibility are common reflecting the fluvial origin of the sand and fine gravel aquifers. Water level fluctuations range from 0.2 to $2.4 \mathrm{~m}$ with the lowest water levels occurring in May/June and 


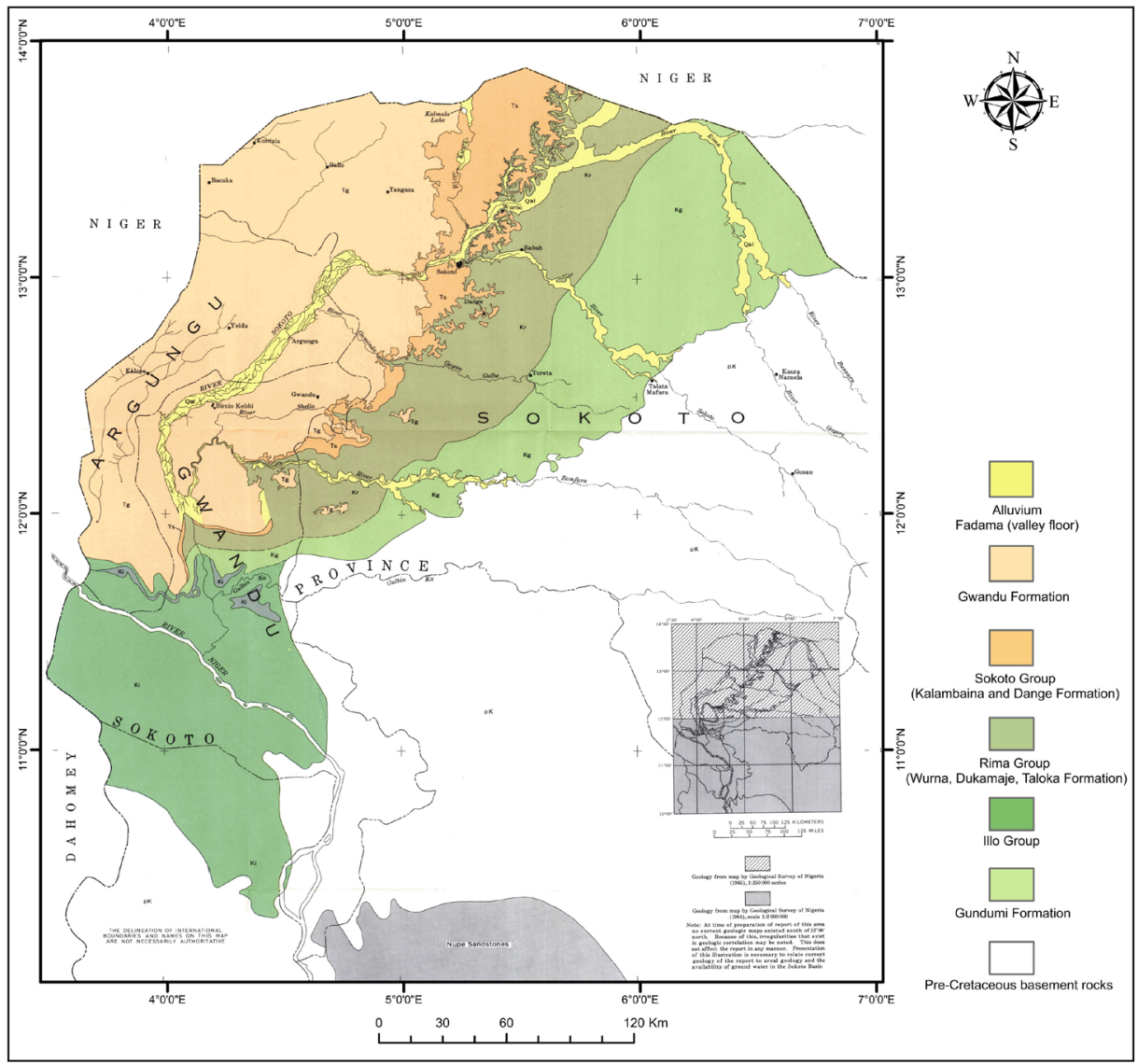

Figure 2. Geological map of Sokoto basin adopted from Hamidu et al. (2017).

the highest water levels occurring in September/October. Recharge to the aquifer occurs primarily through Infiltration of stream flow. However, in the section from Gande to Bagudo, significant upward ground water flow occurs.

\subsubsection{Sokoto River Floodplain}

This floodplain has considerable potential from Sokoto to Talata 1afara. Near the Talata Mafara the river crosses the boundary between the crystalline terrain to the east and the sedimentary terrain to the west. Above this boundary, there are few alluvial deposits along the valley and potential for shallow ground water is poor. Alluvial sands and fine gravels are the main aquifers below Talata Mafara. The transmissibilities of these deposits are in the range 300 to $2300 \mathrm{~m}^{2} /$ day with storage coefficients $10^{-1}$ to $5 \times 10^{-3}$ based on the results of 4 pumping tests. Unconfined to semi-confined aquifer conditions are indicated. Both recharge and discharge boundaries; are shown on the time drawdown plots indicating lateral changes in transmissibility. Water level fluctuations range 0.2 to 0.8 meters in wells near Sokoto Town. Upward ground water flow from the underlying sedimentary Formations is indicated in the lower end of the valley based on boreholes in the vicinity of Sokoto and Raba. In the upper portion of the valley, only minor contribution is expected from the underlying formations, WEC (1988). 


\subsubsection{The Zamfara Floodplain}

This has very significant potential for shallow groundwater from the junction with the Sokoto/Rima River up to the boundary between the crystalline and sedimentary terrains in the vicinity of Bukkuyum. The alluvial sands and fine gravel aquifers have transmissibilities in the range 200 to $1000 \mathrm{~m}^{2} /$ day with storage coefficients $10^{-1}$ to $10^{-7}$. The aquifers vary from unconfined to confined conditions. Complex aquifer conditions are indicated by hydraulic boundaries reflected in the time drawdown plots for the pumping tests as reported by Hamidu et al. (2017). Water level fluctuations range from 0.85 to 1.50 meters in wells near Gummi. In the portion of the floodplain downstream of Jega upward groundwater flow from the underlying sedimentary formations is indicated. Lateral flow appears to dominate in the section Jega to Gummi.

\section{Minor Fadamas in the Sedimentary Terrain}

The Fadamas in these areas mostly have low potential for shallow groundwater development for irrigation purpose. The aquifers are alluvial sands formed by reworking of sediments derived from the surrounding sedimentary formations which are mainly fine grained. Some potential exists in the sedimentary formations underlying the alluvial deposits. Transmissibilities of these aquifers vary from 500 to $600 \mathrm{~m}^{2} /$ day based on the results of 6 pumping tests. Storage coefficients range from $10^{-2}$ to $10^{-5}$ indicating unconfined to semi-confined conditions. Recharge to the aquifers appears to be derived mainly from surface water flow. However, in some cases, for example the Gaminda, a significant upward flow from the underlying sedimentary formation contributes to recharge.

\subsection{Fadamas in Crystalline Terrain}

The aquifers in these areas are alluvial sands and gravels which forms small discontinuous deposits. They have little prospect for obtaining significant amounts of water from the underlying crystalline rocks. The transmissibility of the alluvial aquifers ranges from 150 to $1500 \mathrm{~m}^{2}$ /day based on the results of 5 pumping tests as conducted by WEC (1988). According to the same source, the storage coefficient varies from $10^{-2}$ to $10^{-3}$ indicating mainly unconfined conditions with some semi-confined aquifers. The variability of the transmissibility is Indicative of the variability of the sand and gravel deposits. At most sites fine to medium sands constitute the aquifer material, but in some cases, fine gravel aquifers provide quite good yields from individual tube wells. Recharge to the aquifers is entirely from surface water infiltration.

\section{Afaka (Rivers Chidawakil Chikaji)}

The Fadama of Chikagi/Chidawaki has an aerial extent of $23.6 \mathrm{~km}^{2}$ (Figure 3) A group of four boreholes designated as GWR $-1 / 1$, GWR $-1 / 2$, GWR $-1 / 3$ and GWR $-1 / 4$ were drilled, pumped-tested and monitored for the construction of the borehole hydrograph. The drilling was preceded by surface geophysical investigation using resistivity methods, Eduvie et al. (1999). The results of the drilling show that the only significant aquifer is the alluvium of the Fadama and 


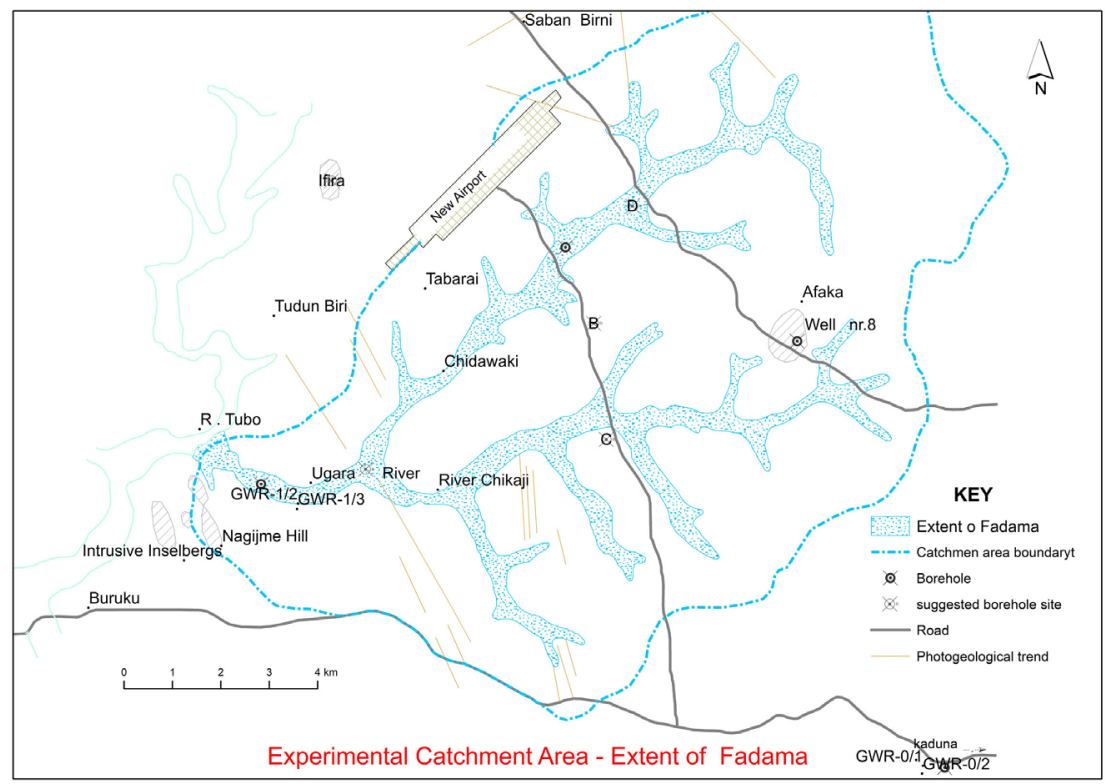

Figure 3. Location of alluvium (Fadama) boreholes at Chidawaki/Chikaji (GWRD, 1986).

the underlying weathered zone of the basement complex (Figure 3). The aquifer consists of alluvial sand and gravel, containing significant quantities of vegetation and wood remains. It is underlain by clayey silt of the weathered zone grading down into sand-size particles and fragments of decomposed basement rocks, GWRD (1986). The aquifer is phreatic with the water table lying about 2.0 $\mathrm{m}$ below ground surface. The thickness varies from $14.0 \mathrm{~m}$ at borehole GWR $-1 / 1$ to $26.0 \mathrm{~m}$ at borehole GWR $-1 / 3$. A cross-section of the area is shown in Figure 5 GWRD (1986). The results of the pumping test are presented in Table 1 .

\section{River Gurara Alluvium}

The investigation of the potentials of the alluvium on the flood plain of the River Gurara (Figure 4) was principally aimed at using the raw water source for the Kaduna Multi State Water Supply Project to supply Kwoi town and environs. To prove the existence of the anticipated coarse alluvium from geophysical investigations, a test drilling and pump test of three boreholes were carried out. The boreholes were drilled by augering and vibrobailing, with one of the boreholes terminating at $8.0 \mathrm{~m}$ depth whilst the other two terminated at $7.0 \mathrm{~m}$ depth, Eduvie et al. (1999) coarse sands were encountered in each hole beneath the top surface silt-fine sands. The details of the pump test results are presented in Table 2.

\section{Fadama Potential}

Generally, potentials for groundwater development along several floodplains is good to excellent including sections of the Kaduna, Galma, Karami, Kachia, Tubo, Kuri, and Shawu Rivers. Shown in Figure 3, is the location of Alluvium (Fadama) boreholes at Chidawaki/Chikaji and Figure 4 shows the location of Gurara Fadama. The Pumping test data of sixteen (16) tube wells in flood plain and other parts of Kaduna is listed in Table 3 showing pumping yield range of 


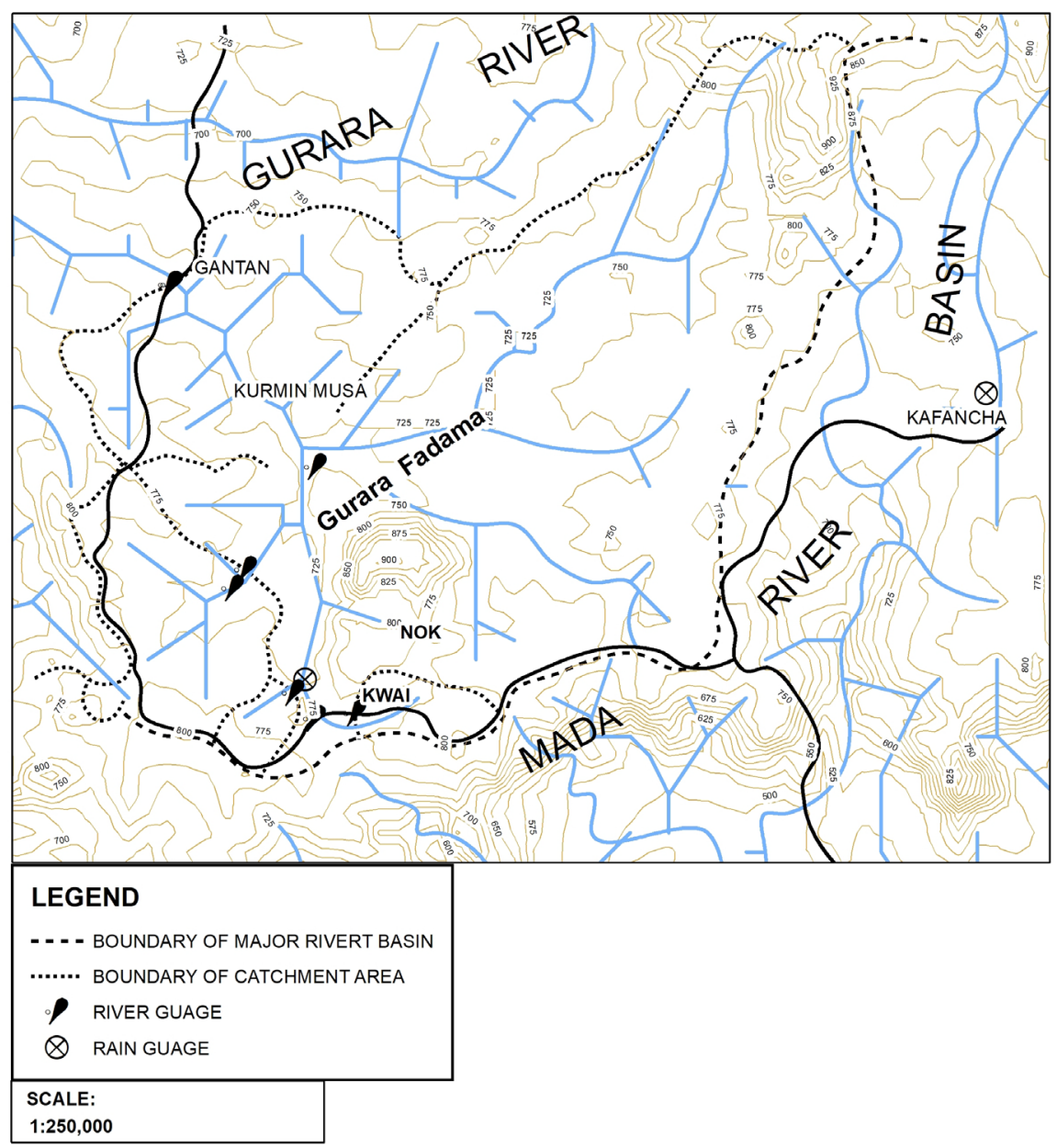

Figure 4. Location of Gurara Fadama adopted from Eduvie \& Ndahi (2012).

Table 1. Borehole characteristics at Chikaji/Chidawaki Fadam.

\begin{tabular}{lcccc}
\hline Borehole No. & $\begin{array}{c}\text { Yield } \\
\left(\mathrm{m}^{3} / \mathrm{d}\right)\end{array}$ & $\begin{array}{c}\text { Transmissivity } \\
\left(\mathrm{m}^{2} / \mathrm{d}\right)\end{array}$ & Storativity & Method \\
\hline GWR -1/2 PZ & & 22.0 & 0.0014 & Semi-equilibrium Jacob \\
GWR-1/3 PZ & 92.3 & 0.001 & Semi-equilibrium Jacob \\
GWR-1/4 PZ & 30 & & Semi-equilibrium Jacob \\
GWR-1/2 PM & 177.84 & 31 & & Semi-equilibrium Theis recovery \\
GWR-1/3 PZ & 104 & & Semi-equilibrium Theis recovery \\
GWR-1/4 PZ & 25 & & Noni-equilibrium Jacob \\
GWR-1/4 PZ & 32 & 0.0088 & \\
\hline
\end{tabular}

(Note: PZ is piezometer and PM is pumping boreholes) GWRD (1986).

Table 2. River Gurara alluvium (Fadama) pumping test results.

\begin{tabular}{cccccc}
\hline Borehole No & Depth $(\mathrm{m})$ & Yield $\left(\mathrm{m}^{3} /\right.$ day $)$ & $\mathrm{T}\left(\mathrm{m}^{2} /\right.$ day $)$ & $\mathrm{S}$ & Method \\
\hline BH 1 (Piezometer) & 7.0 & & 223 & & \\
Pumping BH 2 & 8.0 & 432 & 292 & & Jacob's \\
BH 3 (Piezometer) & 7.0 & & 283 & $9.8 \times 10^{-4}$ & \\
\hline
\end{tabular}


Table 3. Aquifer potentials of some Fadama in Kaduna state.

\begin{tabular}{|c|c|c|c|c|c|c|}
\hline S/NO & Flood plain & Villages & $\begin{array}{l}\text { Depth } \\
\text { (m) }\end{array}$ & $\begin{array}{l}\text { Yield } \\
1 / \text { sec }\end{array}$ & $\begin{array}{c}\text { Transmissivity } \\
\mathrm{m}^{2} / \text { day }\end{array}$ & Storativity \\
\hline 1. & Kaduna River & $\begin{array}{l}\text { Manchok, Doka, } \\
\text { Kaduna, } \\
\text { Mariri, Gwaraji }\end{array}$ & $2.0 \mathrm{~m}$ & $2.0 \mathrm{~L} / \mathrm{S}$ & $\begin{array}{c}100-265 \mathrm{~m}^{2} / \text { day } \\
1400 \mathrm{~m}^{2} / \text { day }\end{array}$ & $\begin{array}{c}0.1 \\
0.36\end{array}$ \\
\hline 2. & $\begin{array}{c}\text { Galma River } \\
\text { (upstream) }\end{array}$ & $\begin{array}{l}\text { Galadimawa, } \\
\text { Gubuchi, Kogi, } \\
\text { Lungu, Kuzuntu }\end{array}$ & $9 \mathrm{~m}$ & $2 \mathrm{~L} / \mathrm{S}$ & $\begin{array}{l}\text { Transmissivity } \\
\text { ranges from } \\
2626 \mathrm{~m}^{2} / \text { day at } \\
\text { Gubuchi to } \\
18 \mathrm{~m}^{2} / \text { day at } \\
\text { Maigana the } \\
\text { average was } \\
120 \mathrm{~m}^{2} / \text { day }\end{array}$ & $0.02-0.4$ \\
\hline 3. & Karami River & $\begin{array}{l}\text { Kauru, Lere, } \\
\text { Lemoro, } \\
\text { Galadimawa, } \\
\text { Saminaka }\end{array}$ & & $2 \mathrm{~L} / \mathrm{S}$ & $\begin{array}{c}827 \mathrm{~m}^{2} / \text { day } \\
\text { at Kauru to } \\
165 \mathrm{~m}^{2} / \text { day } \\
\text { at Lere }\end{array}$ & $0.04-0.4$ \\
\hline 4. & $\begin{array}{l}\text { Galma River } \\
\text { (Downstream) }\end{array}$ & $\begin{array}{l}\text { Vizzara, Zaria, } \\
\text { Igabi, Burgi, } \\
\text { Parda, Rihogi }\end{array}$ & $10 \mathrm{~m}$ & $1.5 \mathrm{~L} / \mathrm{S}$ & $60 \mathrm{~m}^{2} /$ day & 0.09 \\
\hline 5. & Kogun River & $\begin{array}{c}\text { Jagindi, } \\
\text { Kafanchan, Kogoro }\end{array}$ & $<10 \mathrm{~m}$ & $1.0-1.5 \mathrm{~L} / \mathrm{S}$ & $385 \mathrm{~m}^{2} /$ day & 0.08 \\
\hline 6. & Kachia River & $\begin{array}{c}\text { Gidan } \\
\text { Sarkin Katul, } \\
\text { Adagi, Kachia, } \\
\text { Fage Gamilo }\end{array}$ & $6 \mathrm{~m}$ & $>2 \mathrm{~L} / \mathrm{S}$ & $170 \mathrm{~m}^{2} /$ day & $\begin{array}{l}\text { Could not be } \\
\text { determined }\end{array}$ \\
\hline 7. & Tubo River & $\begin{array}{c}\text { Sabon Birni, } \\
\text { Fatika Dende, } \\
\text { Tunburku, Buruku, } \\
\text { MarabaFatika }\end{array}$ & $<8 \mathrm{~m}$ & $1.5-2 \mathrm{~L} / \mathrm{S}$ & $112-460 \mathrm{~m}^{2} /$ day & $0.41-0.0001$ \\
\hline 8. & Kuri River & $\begin{array}{c}\text { Kabene, } \\
\text { Garun Kurama, } \\
\text { Goshere }\end{array}$ & $7-9 m$ & $>2 \mathrm{~L} / \mathrm{S}$ & $534 \mathrm{~m}^{2} /$ day & 0.30 \\
\hline 9. & Gurara River & $\begin{array}{l}\text { Jere, Katari, } \\
\text { Sabon Isharu, } \\
\text { Kurmin Mussa }\end{array}$ & $9 \mathrm{~m}$ & $1 \mathrm{~L} / \mathrm{S}$ & $97 \mathrm{~m}^{2} /$ day & 0.2 \\
\hline 10. & Damari River & $\begin{array}{c}\text { Kuyellow, } \\
\text { Damari, Zato }\end{array}$ & $9 \mathrm{~m}$ & $1.5-2.0 \mathrm{~L} / \mathrm{S}$ & $250 \mathrm{~m}^{2} /$ day & $0.02-0.03$ \\
\hline 11. & Dinya River & $\begin{array}{l}\text { Gidan Bussa, } \\
\text { Kurmin Kare, } \\
\text { Gidan Mangwa }\end{array}$ & $<7 \mathrm{~m}$ & $1 \mathrm{~L} / \mathrm{S}$ & $70 \mathrm{~m}^{2} /$ day & \\
\hline 12. & $\begin{array}{l}\text { Sanga - Gimi } \\
\text { Rivers }\end{array}$ & $\begin{array}{l}\text { Godogodo, } \\
\text { Guja, Sanga, } \\
\text { Kurmin Goro, } \\
\text { Fadan Karshin }\end{array}$ & $<8 \mathrm{~m}$ & $0.75-1.5 \mathrm{~L} / \mathrm{S}$ & $50-100 \mathrm{~m}^{2} /$ day & $0.01-0.3$ \\
\hline 13. & Shayu & Kuda'a & $<10 \mathrm{~m}$ & $>2 \mathrm{~L} / \mathrm{S}$ & $100 \mathrm{~m}^{2} /$ day & 0.0015 \\
\hline 14. & Kusheriki River & $\begin{array}{c}\text { Bagoma, Kwungi, } \\
\text { Doka, Marmara, } \\
\text { Hayin Gaye }\end{array}$ & $<8 \mathrm{~m}$ & $1.5 \mathrm{~L} / \mathrm{S}$ & $200 \mathrm{~m}^{2} /$ day & $0.16-0.41$ \\
\hline
\end{tabular}




\section{Continued}

\begin{tabular}{cccccc}
\hline 15. Wora River & $\begin{array}{l}\text { Wazo, } \\
\text { Kwagiri }\end{array}$ & $<8 \mathrm{~m}$ & $0.75-1.5 \mathrm{~L} / \mathrm{S}$ & $50-100 \mathrm{~m}^{2} /$ day & $0.01-0.3$ \\
16. Mariga River & $\begin{array}{l}\text { Kwadaga, } \\
\text { Romdegi }\end{array}$ & $<7 \mathrm{~m}$ & $0.75-1.5 \mathrm{~L} / \mathrm{S}$ & $50 \mathrm{~m}^{2} /$ day & $0.01-0.3$
\end{tabular}

Source: WEC (1988) and Eduvie \& Ndahi (2012).

$0.75 \mathrm{~L} / \mathrm{Sec}$ to $2 \mathrm{~L} / \mathrm{sec}$. Groundwater is present in aquifers composed of alluvial deposits above bedrocks and fracture system. Shown in Figure 5 is the hydrogeological cross-section at Chidawaki/Chikaji Fadama Eduvie et al. (1999), Eduvie \& Ndahi (2012).

\subsection{The Hadejia Jama'are Komadugu-Yobe River Basin}

The Komadugu-Yobe River Basin (Figure 1) is situated in the Sudan-Sahel zone of northeast Nigeria $\left(\sim 85,000 \mathrm{~km}^{2}\right.$; and southeast Niger $\left(\sim 63,000 \mathrm{~km}^{2}\right.$, Oyebande, 2001). Most of the flow ( 80\%) in the Hadejia River system, which is a tributary of the Yobe River, is controlled upstream by the Tiga Dam (completed in 1974) and Challawa Dam (completed in 1992, Figure 1). All three tributaries of the Yobe River are effluent until they reach the geological boundary between the largely impermeable rocks of the Basement Complex and the permeable sands, gravels and clays of the fluviatile and lacustrine Chad Formation where their regime changes to influent system Hamidu et al. (2017).

The mean annual rainfall ranges from over $1000 \mathrm{~mm}$ in the upstream Basement Complex area around Kano, to approximately $400 \mathrm{~mm}$ in the middle part of the basin and less than $300 \mathrm{~mm}$ near Lake Chad. However, climatic variability has resulted in these mean annual rainfall values being unrepresentative for different periods. Hess et al. (1995), calculated an average decline in annual rainfall of $8 \mathrm{~mm} \cdot \mathrm{yr}^{-1}$ between 1961-1990 for the north-eastern arid zone of Nigeria (i.e. the middle and lower part of the basin). Since the mid-1990s the decreasing trend in annual rainfall seems to have been reversed with a recent trend of increase in average annual precipitation, Oyebande (2001).

\subsection{Other Minor Fadama Areas in This Region Include the}

\section{Madachi Fadama (Hadejia-Nguru wetlands)}

Although most of the irrigation practiced in this basin is the use of surface water from rivers and Dams, there are areas that use the shallow groundwater of the alluvial Fadama/floodplains for, this purpose. The following sections reviewed three areas within the basin which utilizes and depends on the Fadama shallow groundwater resources for both domestic and irrigation needs.

This surface water body is form by the flooded waters of the Hadejia and Jama'are rivers which are ephemeral with $80 \%$ of the run off occurring in the months of August/September and this is responsible for the recharge of the shallow alluvial aquifer recharge, Hollis \& Thompson (1993). A total of 230,000 ha of cultivated floodplain have being estimated for the wetlands, Mukhtar (2018). 


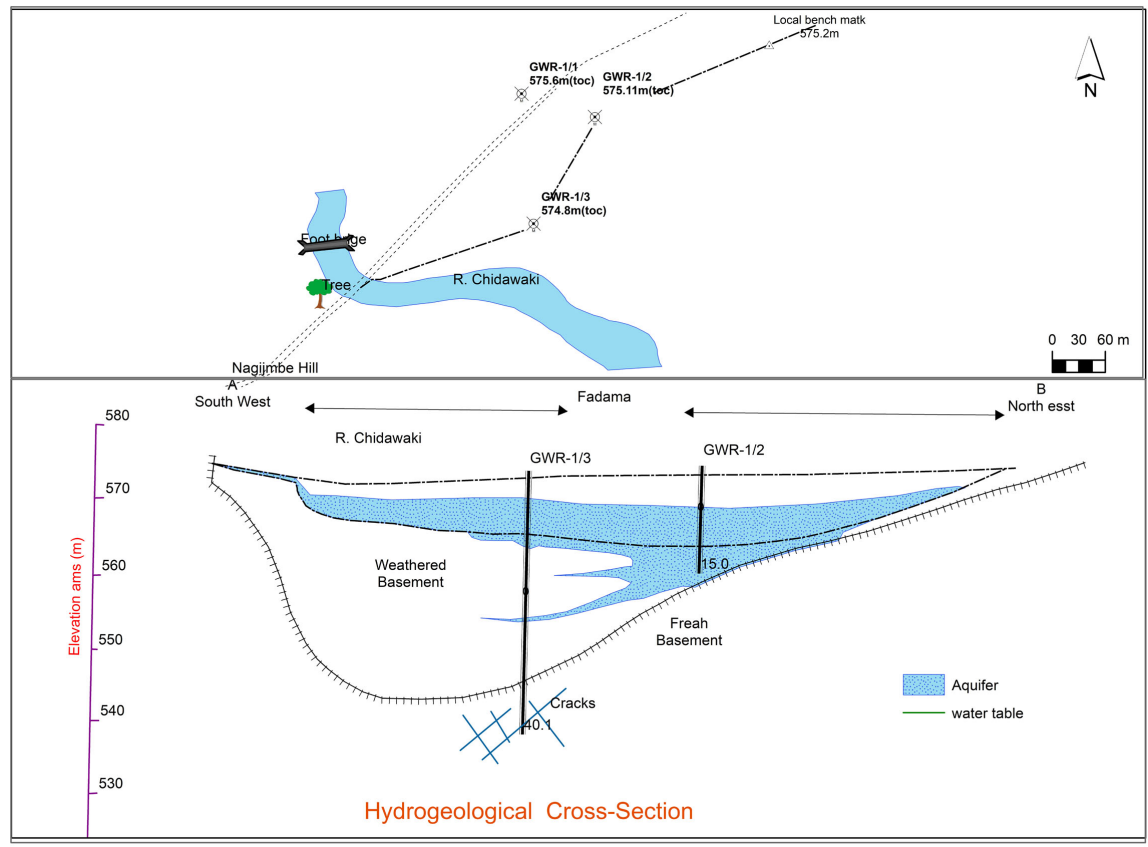

Figure 5. Hydrogeological cross-section at Chidawaki/Chikaji Fadama (GWRD, 1986).

According to a survey carried out, Barbier et al. (1993), a total of 963 tube wells has been drilled in the $66 \mathrm{~km}^{2}$ Madachi Fadama but only 309 are operational and are used for the abstraction of groundwater. Maximum depths of $9 \mathrm{~m}$ have been recorded for the tube wells, while static water level is at 6 or $7 \mathrm{~m}$ and aquifer recharge is dependent on the flooding of the wetlands during the raining season.

\section{Katarko Village River Anumma (Gongola River tributary)}

This Fadama is classified as seasonal stream side Fadama, Acharya \& Barbier (2000), which is characterized with low gradient and poorly defined channels which leads to the deposition of clay, organic materials and debris, which resulted over time to the development of interbedded layers of silt, clay, sand and silty loam overlying the sandy materials. These irregularities give rise to pockets of aquifers through-out the floodplain which are either overlain by aquitard or occur as parched aquifers above thin impervious materials, Tarhule \& Woo, (1997). Hydraulic conductivity for the shallow aquifer ranges between 100 to 101 $\mathrm{m} \cdot \mathrm{d}^{-1}$, aquifers with high conductivity values have thick sand layer greater than $0.9 \mathrm{~m}$, when it is extensive it can yield water up to $5000 \mathrm{ld}^{-1} \cdot \mathrm{m}^{-2}$ without any appreciable drawdown, while shallow hand dug wells in the Fadama have a depth that rarely exceed $4 \mathrm{~m}$.

\section{Bauchi Fadama shallow groundwater on Jama' are and Gongola rivers}

The Gongola and Jama'are Rivers system are characterized by shallow Fadama areas, with substantial part of the Hadejia-Jama'are river basin lying in Bauchi state. Accordingly Turner, evaluated the shallow groundwater potentials of the Fadama areas on the Jama'are and Gongola Rivers within Bauchi State, their study revealed Tube wells on the Jama'are to have depths that range from 7.05 to $12.23 \mathrm{~m}$, with a yield that is from 0.45 to $6.05 \mathrm{l} / \mathrm{s}$ and recorded static water levels 
of wells has a range of 2.32 to $5.62 \mathrm{~m}$. The River Gongola Fadama area has well depths that range from 2.68 to $6.84 \mathrm{~m}$ with yields range of 1.66 to $9.43 \mathrm{l} / \mathrm{s}$ while static water levels in tube wells stood between 1.03 and $3.3 \mathrm{~m}$. their findings revealed more groundwater potentials for the Gongola Fadama area compared to Jama'are which can be traced to the amount of rainfall and subsequently flooded waters received by both rivers.

Yola shallow Fadama groundwater of the Upper Benue River

The Upper Benue basin with a catchment area of about $750 \mathrm{~km}^{2}$ has the Benue River as the largest perennial river that is fed by two major tributaries of River Faro and Mayo Kebbi with a discharge of about $3500 \mathrm{~m}^{3} / \mathrm{s} 14$. Abubakar Sadiq et al. (2014). Before the construction of the Lagdo Dam the flow of the Benue at Yola gauging station in November to June was 10 to $20 \mathrm{~m}^{3} / \mathrm{s}$, Toro (1997). However after the Dam was constructed the flow triple to about $60 \mathrm{~m} 3 / \mathrm{s}$, this has led to increase in groundwater level in the alluvial aquifers in the Benue downstream in the Yola region, Ankindawa et al. (2015). The alluvial deposit of the Benue River and its tributaries are mainly sands, clays, silts, silty-clays and pebbly sands Ankindawa et al. (2015). According to Abubakar Sadiq et al. (2014), the alluvial flood plains has thick sand bed that measured between 5 to $18 \mathrm{~m}$ in thickness with impervious aquitard layers of clayey silt and sandstone at its base. Numerical modelling carried out by Abubakar Sadiq et al. (2014) on the floodplain aquifers of the Benue river revealed groundwater extraction rate of $172.8 \mathrm{~m}^{3} / \mathrm{d}$, considering the floodplain model to be a single hydrogeological layer, a hydraulic conductivity value of $2.884 \times 10^{-1} \mathrm{~m} / \mathrm{s}$ was obtained, they went further to show that water exchange between the river and floodplain occur through the river bed and the alluvial floodplain aquifer. Simulated river seepage to the flood plain alluvial aquifer was computed to be $212,372 \mathrm{~m}^{3} /$ day $(75 \%)$ and the discharge through the alluvial aquifer by abstraction was $165,775 \mathrm{~m}^{3} /$ day (56\%).

\section{River Katsina Ala Shallow floodplain aquifer}

River Katsina Ala is a major tributary of the Benue River; it flows 200 miles, $320 \mathrm{~km}$ in the Cameroon and has an area of about $2402 \mathrm{~km}^{2}$. Pumping test analysis conducted on 5 tube wells on the floodplains of the Katsina Ala River by Obiefuna et al. (1999), gives a yield that ranges from 1719.36 to $3075.94 \mathrm{~m}^{3} /$ day with tube wells depsths ranging from 6.8 to $9.2 \mathrm{~m}$, static water levels in the shallow wells are from 3.7 to $5.25 \mathrm{~m}$. Computed transmissibility values are from 205.92 to $1157.76 \mathrm{~m}^{2}$ /day with a maximum drawdown value of $1.83 \mathrm{~m}$ recorded for the alluvial aquifer on this floodplain.

\section{Conclusion}

Northern Nigeria is blessed with low lying Fadama area totaling about 0.9 million ha in size that is formed from the annual flooding rivers which deposit thick sands, clays and silty materials which are the products of weathered basement and sedimentary rocks from uplands and surrounding areas adjacent to these 
rivers courses. Out of this figure, the Sokoto River basin alone contains the $280,000 \mathrm{~km}^{2}$ which is the largest in the whole northern Nigeria. The alluvial sandy materials constitute shallow high yielding aquifers with attending thickness of 18 to $20 \mathrm{~m}$ in the major Fadama areas. Alluvial shallow aquifers of the Fadama are characterized by low drawdown, high transmissibilities and hydraulic conductivity values as well as high yield, with static water levels that are less than 7 meters. Tube wells and Hand dug wells on these Fadamas have depth that ranges from 4 to 25 meters and is recharged by the rivers and during floods events.

These shallow groundwater resources are used for domestic and livestock watering purposes and the most importantly for irrigation, for dry season farming during the dry period in the Sudano-Sahel region and in the arid to semi-arid draught prone areas of the northern Nigeria, this makes it possible for the all year round farming to be practice in the Northern region.

\section{Conflicts of Interest}

The authors declare no conflicts of interest regarding the publication of this paper.

\section{References}

(2005). Irrigation in Africa in Figures: AQUASTAT Survey. FAO Land and Water Development Division, Food and Agriculture Organization of the United Nations.

Abubakar Sadiq, A., Sunusi, A. A., Ahmad, D., \& Umara, G. B. (2014). Characteristics of Irrigation Tube Wells on Major River Floodplains in Bauchi State, Nigeria. Revista Ambiente \& Agua-An Interdisciplinary Journal of Applied Science, 9, 602-609. https://doi.org/10.4136/ambi-agua.1314

Acharya, G., \& Barbier, B. E. (2000). Valuing Groundwater Recharge through Agricultural Production in the Hadejia-Nguru Wetlands in Northern Nigeria. Agricultural Economics, 22, 247-259. https://doi.org/10.1111/j.1574-0862.2000.tb00073.x

Ankindawa, B. A., Bradley, C., Collins, P., \& Leroy, S. A. G. (2015). Modelling the Sustainability of Low-Cost Hand Drilling Methods of Shallow Groundwater Abstraction: The Case of Upper Benue River NE Nigeria. International Journal of Scientific \& Engineering Research, 6, 2062-2088.

Barbier, E. B., Adams, W., \& Kimmage, K. (1993). Economic Valuation of Wetland Benefits. In Hollis et al. (Eds.), The Hadejia-Nguru Wetlands (pp. 48-51). Gland: IUCN.

Eduvie, M. O., Mogekwu, E. A., \& Adanu, E. A. (1999). Aquifer Assessment and Borehole Characteristics in Parts of Kaduna and Environs. Water Resources Journal of Nigerian Association of Hydrogeologists, 10, 38-45.

Eduvie, O. M., \& Ndahi, A. K. (2012). Groundwater Potential of Fadama for Irrigation: Case Study of Chikaji/Chidawaki and Gurara Rivers Catchments in Kaduna State, NW Nigeria. Proceedings of 3rd National Water Conference.

Groundwater Research Department GWRD (1986). FDWR/EDF Water Resources Project. Final Report Vol. 1, II and III.

Hamidu, H., Lawal, M., Abdulganiyu, Y., Kwaya, M. Y., Grema, H. M., Ibrahim, H. A., Kitha, M., \& Yelwa, N. A. (2017). Re-Evaluation of Shallow Floodplain Aquifers Ground- 
water Potentials and Storage of Sokoto Basin, Northwestern Nigeria. American Journal of Water Resources, 5, 72-84. http://pubs.sciepub.com/ajwr/5/3/3 https://doi.org/10.12691/ajwr-5-3-3

Hess, T. M., Stephens, W., \& Maryah, U. M. (1995). Rainfall Trends in the North East Arid Zone of Nigeria 1961-1990. Agricultural and Forest Meteorology, 74, 87-97. https://doi.org/10.1016/0168-1923(94)02179-N

Hollis, G. E., \& Thompson, J. R. (1993). Water Resources Developments and Their Hydrological Impacts. In G. E. Hollis, W. M. Adams, M., \& Aminu-Kano (Eds.), The Hadejia-Nguru Wetlands. Gland, Cambridge: IUCN.

Mukhtar, I. (2018). Flood Vulnerability Risk Assessment of Kano Metropolis. An Unpublished Ph.D. Thesis, Zaria: Department of Geography, Ahmadu Bello University.

Obiefuna, G. I., Nur, A., Baba, A. U., \& Bassey, N. E. (1999). Geological and Geotechnical Assessment of Selected Gully Sites, Yola Area Northeast, Nigeria. Journal of Environmental Hydrology, 7, 1-13.

Oyebande, L. (2001). Stream Flow Regime Change and Ecological Response in the Lake Chad Basin in Nigeria. Hydro-Ecology: Linking Hydrology and Aquatic Ecology, Birmingham, July 1999, IAHS Publ. No. 266, 101-111.

Swindell, K. (1986). Population and Agriculture in the Sokoto Rima of North-Western Nigeria: A Study of Political Intervention, Adoption and Change, 1800-1980. Cahiers Detudes Africanes, 26, 75-111. https://doi.org/10.3406/cea.1986.2167

Tarhule, A., \& Woo, M. (1997). Characteristics and Use of Shallow Wells in a Stream Fadama: A Case Study in Northern Nigeria. Applied Geography, 17, 29-42. https://doi.org/10.1016/S0143-6228(96)00023-9

Tarhule, A., \& Woo, M.-K. (1997). Characteristics and Use of Shallow Wells in a Stream Fadama: A Case Study in Northern Nigeria. Applied Geography, 17, 29-42.

Toro, S. M. (1997). Post-Construction Effects of the Cameroonian Lagdo Dam on the River Benue. Journal of CIWEM, 11, 109-113. https://doi.org/10.1111/j.1747-6593.1997.tb00100.x

Wardrop Engineering Consultants WEC (1988). Sokoto Fadama Shallow Groundwater Studies. A Report Submitted to Sokoto Agricultural and Rural Development Authority. 